Cita: Mateus, N.; Gonçalves, B.; Exel, J.; Esteves, P.; Sampaio, J. (2020). Short-term effects of adding 1-m wide to each side of the basketball court on youth players' performance. Cuadernos de Psicología del Deporte, 20(3), 82-94

\title{
Short-term effects of adding 1-m wide to each side of the basketball court on youth players' performance
}

\section{Efectos a corto plazo de aumentar 1-m de ancho a cada lado de la cancha de baloncesto en el rendimiento de los jóvenes jugadores}

\section{Efeitos a curto prazo de aumentar o campo de basquetebol 1-m para cada lado no rendimento de jovens jogadores de basquetebol}

\author{
Mateus, $\mathrm{N}_{1,2}$, Gonçalves, B3,4,5, Exel, J6, Esteves, $\mathrm{P}_{1,7}$, Sampaio, J1,2. \\ 1 Research Center in Sports Sciences, Health Sciences and Human Development, CIDESD, CreativeLab \\ Research Community, Vila Real, Portugal; 2 Department of Sports Science, Exercise and Health, \\ University of Trás-os-Montes e Alto Douro, Vila Real, Portugal; з Departamento de Desporto e Saúde, \\ Escola de Ciências e Tecnologia, Universidade de Évora, Évora, Portugal; 4 Comprehensive Health \\ Research Centre (CHRC), Évora, Portugal; 5 Portugal Football School, Portuguese Football Federation, \\ Oeiras, Portugal; 6 Department of Sport Science, Center for Sports Science and University Sports, \\ University of Vienna Vienna, Austria; 7 Polytechnic Institute of Guarda, Guarda, Portugal
}

\begin{abstract}
This study aimed to identify short-term effects on basketball players' physical responses, technical performance, and tactical behaviour when the court dimension is increased $1-\mathrm{m}$ wide to each side. Fourteen youth players participated in 5 vs. 5 simulated basketball games, under two different conditions: regular court $(28 \times 15 \mathrm{~m})$ and wider court (28x17m, 1-m wider for each side). Besides the assessment of physical and technical indicators, positional data were also used to compute the following variables: distance to the nearest opponent, distance to the nearest teammate, stretch-index and distance between centroids. Results indicated that in the wider court condition, the dispersion of player's displacement trajectories during the offensive phase increased, which had slight repercussions on their physical responses and in the teams' playing patterns. Conversely, during the defensive phase, players tended to move within the regular spatial references, regardless of court width manipulation. Overall, this study emphasizes that short-term effects of changing the court dimensions are relatively negligible, suggesting that informational constraints might require longer time-scales to yield robust changes in players' performance.
\end{abstract}

Keywords: basketball; performance analysis; collective behaviour; time-motion.

\section{RESUMEN}

El propósito de este estudio fue identificar los efectos a corto plazo en las respuestas físicas, técnicas y tácticas de jóvenes jugadores de baloncesto cuando la dimensión de la cancha aumenta 1-m de ancho en cada lado. Catorce jugadores jóvenes participaron en juegos simulados de baloncesto de 5 vs. 5 , en dos condiciones diferentes: cancha 


\section{Effects of increasing the court on basketballers' performance}

regular $(28 \times 15 \mathrm{~m})$ y cancha más amplia $(28 \times 17 \mathrm{~m}, 1-\mathrm{m}$ de ancho a cada lado). Además de la evaluación de los indicadores físicos y técnicos, también se utilizaron datos de posición para calcular las siguientes variables: distancia al oponente más cercano, distancia al compañero de equipo más cercano, coeficiente de dispersión del equipo y distancia entre los centroides de los equipos. Los resultados indicaron que, en la condición de cancha más amplia, la dispersión de las trayectorias de movimiento de los jugadores durante la fase ofensiva aumentó, lo que tuvo ligeras repercusiones en sus respuestas físicas y en los patrones de juego de los equipos. En contrapartida, durante la fase defensiva, los jugadores tienden a moverse dentro de las referencias espaciales regulares, independientemente de la manipulación del ancho de la cancha. En general, este estudio enfatiza que los efectos a corto plazo de cambiar las dimensiones de la cancha son relativamente ligeros, lo que sugiere que las restricciones informativas pueden requerir bastante más tiempo para producir cambios concretos en el rendimiento de los jugadores.

Palabras clave: baloncesto; análisis de rendimiento; comportamiento colectivo; tiempo-movimiento.

\section{RESUMO}

Este estudo teve como objetivo identificar os efeitos a curto prazo na performance física, técnica e tática de jovens jogadores de basquetebol, quando a largura do campo é aumentada 1-m para cada lado. Catorze jovens jogadores participaram em jogos simulados de 5 vs. 5 , em dois contextos distintos: campo regular $(28 \times 17 \mathrm{~m})$ e campo amplo (28x17m, 1-m mais largo para ambos os lados). Paralelamente à avaliação de indicadores físicos e técnicos, foram também recolhidos dados posicionais, com o intuito de calcular as seguintes variáveis: distância ao oponente mais próximo, distância ao companheiro de equipa mais próximo, coeficiente de dispersão da equipa e distancia entre os centroides das equipas. Os resultados demonstraram que no contexto de campo amplo, a dispersão das trajetórias de movimento dos jogadores aumentou durante a fase ofensiva, o que acarretou ligeiras repercussões nos perfis físicos e nos padrões de jogo das equipas. Em contrapartida, durante a fase defensiva, os jogadores tendem a mover-se dentro dos referenciais espaciais, independentemente da manipulação do tamanho do campo. No geral, este estudo realçou que os efeitos a curto prazo de alterar as dimensões do campo são pouco expressivos, o que sugere que os constrangimentos de informação podem requerer substancialmente mais tempo para produzir alterações concretas no rendimento dos jogadores.

Palavras-chave: basquetebol; análise do rendimento; comportamento coletivo; tempo-movimento.

\section{INTRODUCTION}

Over the past few years, the basketball rules have changed regarding time (e.g. segmentation of the game, from halves into quarters, and ball possession duration) and space (e.g. 3-point field-goal area), reflecting in meaningful repercussions in the tactical and physical demands, as well as in players' physiological profiles (Cormery, Marcil, \& Bouvard, 2008). Basketball research has showed that players tend to be taller and heavier, with higher fitness levels, and that game has become more strategic, as a consequence of the teams set up and run multiple offensive plays and sophisticated defenses (Calleja, Tobalina, Santos, Hidalgo, \& Terrados, 2015; Carter, Ackland, Kerr, \& Stapff, 2005; Drinkwater, Pyne, \& McKenna, 2008; Ibáñez, García-Rubio, RodríguezSerrano, \& Feu, 2019). However, the regular court (28-m length $x$ 15-m width) still have the same dimensions. Consequently, the ratio player/space is getting smaller, particularly in professional basketball, as the court frequently seems to be overcrowded. In line with this reasoning, the Spanish professional basketball league recently promoted a preseason tournament (Circuito de Pretemporada 2018) with enlarged court dimensions, that generated a noteworthy influence on players' self-reported effort and coaches' subjective perception of game pattern. Despite these adaptations seemed to be quite promising (e.g. more dynamic and spaced offenses, which may create greater challenges for defensive help and recover actions), no data has been reported on short-term effects of manipulating court dimensions in player performances.

Previous team-sports studies have identified the influence of manipulate the competitive environment (e.g., court configuration, scoring targets, number of players) on players' technical actions, physiological and workload responses and positional performance (Martínez Fernández, García Rubio, \& Ibáñez, 2015; 


\section{Mateus, N., Gonçalves, B., Exel, J., Esteves, P., Sampaio, J.}

Mateus, Goncalves, Weldon, \& Sampaio, 2019; Piñar, Cárdenas, Alarcón, Escobar, \& Torre, 2009; Aguilar Sánchez, Hernández-Mendo, Martín Martínez, Reigal Garrido, y Chirosa Ríos, 2018; Toro, Alonso, \& Egido, 2017). Concerning the court dimension, it was previously reported that enlarging court dimensions increases metabolic demands and affect the individual-team displacements (Casamichana \& Castellano, 2010; Frencken, Van Der Plaats, Visscher, \& Lemmink, 2013; Gonçalves et al., 2017). In this regard, Silva and colleagues (2014) showed that by expanding the available space to play there was an increase in the areas covered by football players which influenced the relationships between their trajectories and distances on the court. Furthermore, previous research in basketball revealed that the increase in the playing space is associated to greater cardiovascular demands (Atl, Köklü, Alemdaroglu, \& Koçak, 2013) and player workload (Vazquez-Guerrero, Reche, Cos, Casamichana, \& Sampaio, 2018). Additionally, Correia (2011) suggested that tactical approaches favouring the enhancement of the playing space might shape the emergence of opportunities (i.e., affordances) to explore a wider range of technical actions, as a result of the increase in the time available for players to perceive and act accordingly (Silva et al., 2014).

Considering that basketball is rooted on uninterruptedly contextual dependency decisions, involving two opposite teams, whose players interact dynamically, interdependently, and adaptively (Sampaio, Gonçalves, Mateus, Shaoliang, \& Leite, 2018), a change in the court dimension would be expected to lead not only to modifications of the game' physical demands but also in players' decision making and collective behaviour.

Thus, it is important to provide new insights on how the changes in the competitive environment may influence individuals' perceptual-motor relations and as their spatiotemporal interactions. This way, coaches can understand better the different game context and develop appropriate strategies to achieve adaptable and functional coordinative behaviours (Sampaio, Gonçalves, Rentero, Abrantes, \& Leite, 2014). Therefore, the present study aimed to identify shortterm effects in basketball players' physical responses, technical performance, and tactical behaviour when the court dimension is increased $1-\mathrm{m}$ wide to each side.

\section{MATERIALS AND METHODS}

\section{Research design}

The present study can be characterized as empirical research, based on a manipulative design with an experimental nature (Ato, López-García, \& Benavente, 2013). Indeed, we intended to assess youth basketball players' overall performance, when playing in a regular basketball court and a larger court (1-m wide to each side). Thus, the research team was responsible for selecting the variables to be analysed and for designing the study methodology, which included the court' width manipulation.

\section{Participants}

Fourteen young basketballers ( $14 \pm 0.9$ years, $54 \pm 9.3$ $\mathrm{kg}$ weight, $173 \pm 10.5 \mathrm{~cm}$ height) were recruited from a local basketball team. The team played at regional level competition and players were involved in three training sessions and one competitive game per week. Players, their legal guardians, and their coach were fully informed about the protocol description and provided written informed consent before data collection. The study protocol was conformed to the recommendations of the Declaration of Helsinki and was approved in compliance of the guidelines stated by the local Institutional Research Ethics Committee (UID/DTP/04045/2019).

\section{Design}

To ensure the assembly of balanced teams, the players were divided into four teams according to the coach' perception about their passing ability, ball control, field-goal shooting and game knowledge. A total of eight $5 \mathrm{vs} .5$ basketball games were performed during two preseason training sessions in two different conditions: i) regular court $(28 \times 15 \mathrm{~m})$ and ii) larger court (28x17m, 1-m wider in each side) (see Figure 4). Each team participated in both game conditions per session, with all players participating in at least one game in each condition. The court characteristics were distributed arbitrarily per session, resulting in an overall of four games played in each condition. Every game had 5-min duration interspersed with a 3-min recovery period and was played according to official basketball rules. All players were previously familiarized with the two-game situations. To encourage high work-rate maintenance, free verbal 


\section{Effects of increasing the court on basketballers' performance}

support was given to all players by their coach, but no technical-tactical feedbacks were allowed. In offence, the players used teams' set plays, but in defence a halfcourt defence was prescribed. To reduce the stoppage time, no free-throws were awarded and in the case of the ball going off, a sufficient number of balls were located around the court to ensure the fast return of the ball into play. Overall, eight games (four at each condition) were considered for analysis.

\section{Methodology}

Positional data were recorded using the WIMU® system (RealTrack Systems, Almería, Spain). Validity and reliability of WIMUß system have been reported previously and their operation and handling are documented elsewhere (Bastida-Castillo et al., 2019). The mean absolute error of measurement is below 5.2 $\pm 3.1 \mathrm{~cm}$ for the $\mathrm{x}$-position and $5.8 \pm 2.3 \mathrm{~cm}$ for the $\mathrm{y}-$ position (Bastida-Castillo et al., 2019). To decrease measurement error and increase the validity and reliability of the system, the players used the same unit across all the game situations. The players' bidimensional coordinates obtained through the WIMU units were exported and computed using dedicated codes written in Matlab® (MathWorks, Inc., Massachusetts, USA). The total distance covered, distance covered at different speeds and the game pace (mean speed for each player at each scenario) were measured as external workload variables. The distance covered at different speeds were standardized into four speed categories and adapted from previous literature as follows: walking ( $\leq 6 \mathrm{~km} / \mathrm{h})$, jogging (6.1 - 12 $\mathrm{km} / \mathrm{h})$, running $(12.1-18 \mathrm{~km} / \mathrm{h})$, and sprinting $(\geq 18.1$ $\mathrm{km} / \mathrm{h}$ ) (Puente, Abian-Vicen, Areces, Lopez, \& Del Coso, 2017). Furthermore, the positional data were used to process the following variables: distance to the nearest opponent (NearOP), distance to the nearest teammate (NearTM), stretch-index (SIX), and distance between centroids (DbC). Each of the variables was processed to calculate the mean value and the coefficient of variation (CV), both for offense and defence phases.

In order to understand effectively how the manipulation of the court' width constraints the exploration of court areas, the court was divided into sixteen zones (adapted from Hughes and Franks (2004)) and the percentage of total time played by each player in each zone was calculated for each condition. Lastly, to collect notational data, all games were recorded with a digital camera (Sony CX625 Handycam $\left.{ }^{\circledR}\right)$. The following individual and team performance variables were registered: field-goals made (FGM), field-goals missed (FGMs), offensive rebounds (OREB), defensive rebounds (DREB) steals (STL), passes (PASS), personal fouls (PF), dribble drives (DD) and ball possessions (BP). The individual performance indicators were normalized according to ball possession to account for differences in game pace. In order to ensure a high inter-rater reliability for all variables, the analysis was accomplished by two experienced researchers in basketball coaching and performance analysis and the results of interrater reliability were deemed as high (kappa coefficients $>.90)$.

\section{Statistical Analysis}

The performance differences between game conditions were accessed through a repeated measures T-Test. Statistical significance was set at $\mathrm{p}<.05$ and calculations were carried using SPSS (IBM SPSS Statistics for Windows, Armonk, NY: IBM Corp.). Additionally, individual differences were analysed with a specific repeated measures spreadsheet (postonly crossover trial) and the positional variables were compared using a spreadsheet to independent analysis (means of different groups' comparison) (Hopkins, 2017). All technical, workload and positional related variables effects were estimated in raw units and uncertainty in the estimate was expressed as $95 \%$ confidence limits. Smallest worthwhile differences were measured using the standardized units multiplied by 0.2 (Hopkins, 2004). Uncertainty in the true effects of the conditions was evaluated with the non-clinical version of magnitude-based inferences. Probabilities were assessed qualitatively and reported using the following scale: $>5 \%$, unclear; $25-75 \%$, possibly; $75-$ $95 \%$, likely; 95-99.5\%, very likely; >99.5\%, most likely. Standardized (Cohen) mean differences and respective $95 \%$ confidence intervals were also computed as magnitude of observed effects, and, thresholds were: <0.2, trivial; 0.6, small; 1.20, moderate; 2.0, large; and >2.0, very large (Hopkins, Marshall, Batterham, \& Hanin, 2009).

\section{RESULTS}

The inferences of technical and workload variables are shown in Table 1, as well as in Figure 1 and Figure 2. Regarding to technical actions, unclear results were 


\section{Mateus, N., Gonçalves, B., Exel, J., Esteves, P., Sampaio, J.}

observed in almost all variables when comparing regular to the wider court, except for STL, which likely decreased. The workload variables presented similar tendencies, as unclear differences were observed for distance covered (offense and defence), sprinting (offense and defence) and running (defence).
On the other hand, walking displacements in offense possible decreased (offense: $-0.94 ; \pm 1.1$, small; raw mean differences, $\pm 95 \% \mathrm{CL}$ ) when playing in the wider court, whereas offensive jogging possibly increased $(1.68 ; \pm 2.2$, small $)$.

Table 1. Descriptive analysis of players' performance measures in varied court dimension.

\begin{tabular}{|c|c|c|c|c|c|}
\hline \multirow{2}{*}{\multicolumn{2}{|c|}{ Variables }} & \multicolumn{2}{|c|}{ Condition $($ mean \pm SD) } & \multirow{2}{*}{$\begin{array}{c}\text { Difference in means } \\
\text { (raw; } \pm 95 \% \mathrm{CL})\end{array}$} & \multirow{2}{*}{$\begin{array}{c}\text { Practical } \\
\text { Inferences }\end{array}$} \\
\hline & & regular & wider & & \\
\hline \multicolumn{6}{|c|}{ Technical/tactical actions } \\
\hline \multicolumn{2}{|c|}{ Field-goals made } & $0.03 \pm 0.10$ & $0.03 \pm 0.10$ & $0.01 ; \pm 0.01$ & likely trivial \\
\hline \multicolumn{2}{|c|}{ Field-goals missed } & $0.05 \pm 0.01$ & $0.05 \pm 0.10$ & $0.01 ; \pm 0.01$ & unclear \\
\hline \multicolumn{2}{|c|}{ Offensive rebounds } & $0.02 \pm 0.01$ & $0.02 \pm 0.01$ & $-0.01 ; \pm 0.01$ & unclear \\
\hline \multicolumn{2}{|c|}{ Defensive rebounds } & $0.02 \pm 0.01$ & $0.02 \pm 0.01$ & $0.01 ; \pm 0.01$ & unclear \\
\hline \multicolumn{2}{|c|}{ Steals } & $0.02 \pm 0.01$ & $0.01 \pm 0.01$ & $-0.01 ; \pm 0.01 *$ & likely $\downarrow$ \\
\hline \multicolumn{2}{|c|}{ Passes } & $0.42 \pm 0.20$ & $0.40 \pm 0.20$ & $-0.02 ; \pm 0.10$ & unclear \\
\hline \multicolumn{2}{|c|}{ Fouls } & $0.01 \pm 0.01$ & $0.01 \pm 0.01$ & $0.00 ; \pm 0.01$ & unclear \\
\hline \multicolumn{2}{|c|}{ Dribble drive } & $0.05 \pm 0.10$ & $0.06 \pm 0.10$ & $0.00 ; \pm 0.01$ & unclear \\
\hline \multicolumn{2}{|c|}{ Possessions } & $0.53 \pm 0.20$ & $0.53 \pm 0.30$ & $0.00 ; \pm 0.1 .0$ & unclear \\
\hline \multicolumn{6}{|l|}{ Workload } \\
\hline \multirow{2}{*}{ Distance covered } & offense & $101.3 \pm 11.2$ & $102.2 \pm 14.2$ & $0.9 ; \pm 4.3$ & unclear \\
\hline & defence & $90.5 \pm 12.7$ & $91 \pm 13.0$ & $0.5 ; \pm 3.2$ & unclear \\
\hline \multirow{2}{*}{ Walking } & offense & $29.8 \pm 3.1$ & $28.9 \pm 3.7$ & $-0.9 ; \pm 1.1$ & possible $\downarrow$ \\
\hline & defence & $33.8 \pm 4.0$ & $33 \pm 3.7$ & $-0.8 ; \pm 1$ & possible $\downarrow$ \\
\hline \multirow{2}{*}{ Jogging } & offense & $39.8 \pm 5.9$ & $41.5 \pm 6.4$ & $1.7 ; \pm 2.2$ & possible $\uparrow$ \\
\hline & defence & $35.5 \pm 8.7$ & $36.1 \pm 8.7$ & $0.6 ; \pm 2.4$ & likely trivial \\
\hline \multirow{2}{*}{ Running } & offense & $27.6 \pm 9.9$ & $27.3 \pm 10.6$ & $-0.3 ; \pm 3.3$ & unclear \\
\hline & defence & $17.7 \pm 7.4$ & $18.6 \pm 8.2$ & $0.9 ; \pm 2.1$ & possible $\uparrow$ \\
\hline \multirow{2}{*}{ Sprinting } & offense & $5.6 \pm 5.1$ & $5.9 \pm 6.8$ & $0.3 ; \pm 2.1$ & unclear \\
\hline & defence & $3.5 \pm 3.4$ & $3.2 \pm 2.8$ & $-0.3 ; \pm 1.1$ & unclear \\
\hline
\end{tabular}

Legend: *statistically significant differences at $\mathrm{p}<.05$; ** statistically significant differences at $\mathrm{p}<.001$. Symbols: $\downarrow=$ decrease; $\uparrow=$ increase. 


\section{Effects of increasing the court on basketballers' performance}

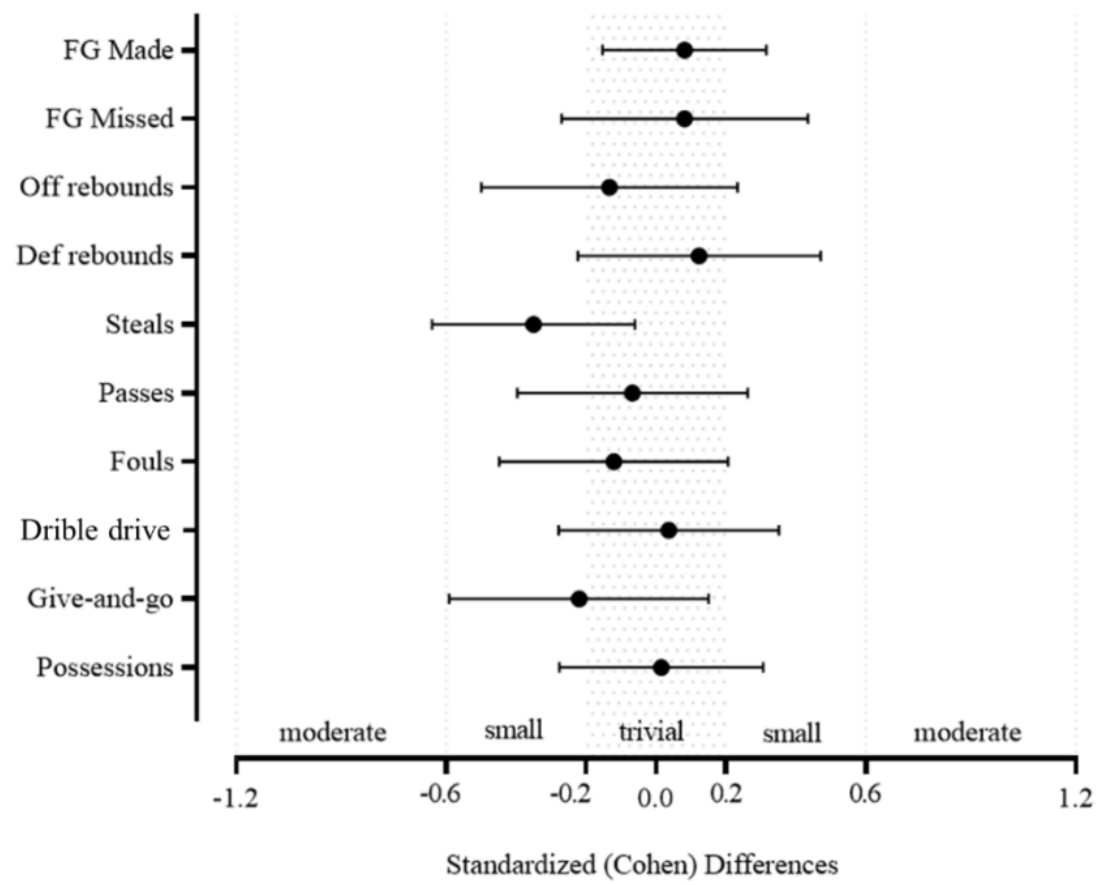

Figure 1. Standardized (Cohen) differences of technical variables according to game condition analysis. Error bars indicate uncertainty in the true mean changes with $95 \%$ confidence intervals.

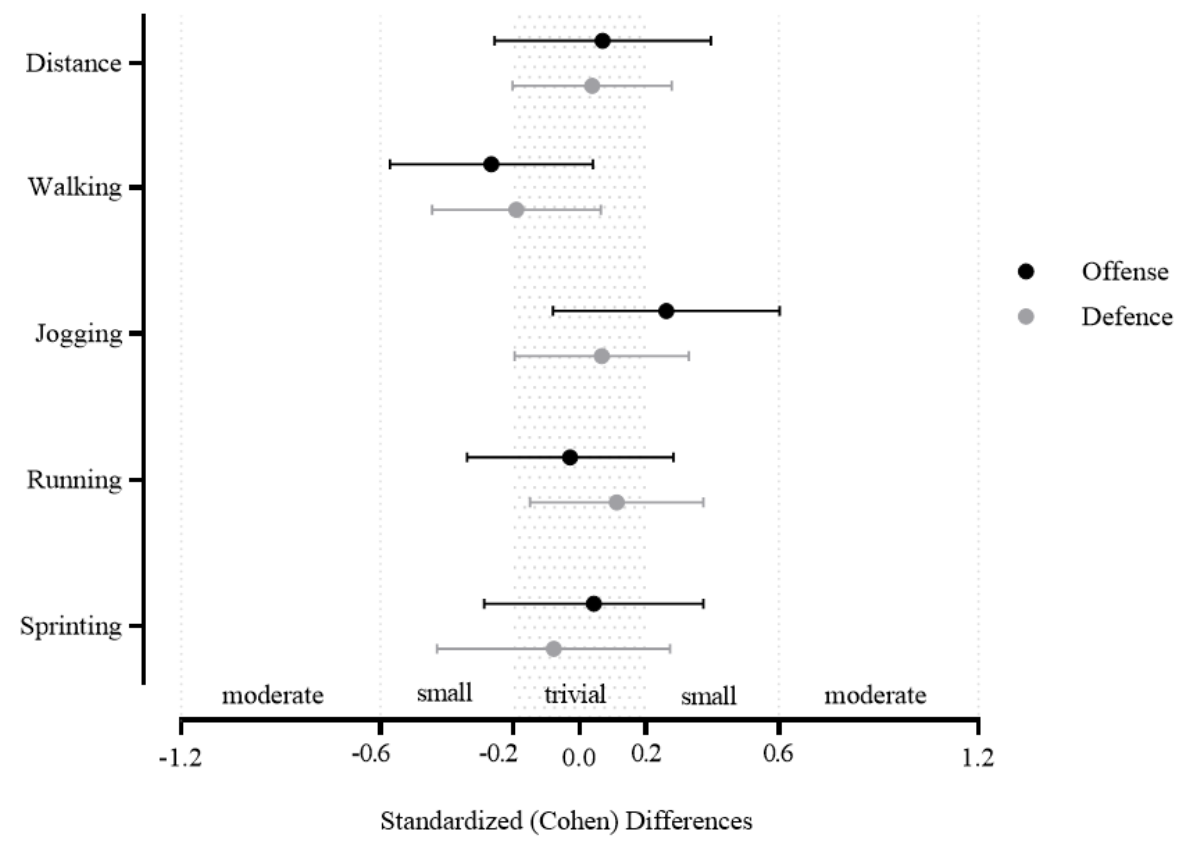

Figure 2. Standardized (Cohen) differences of workload variables according to game condition analysis. Error bars indicate uncertainty in the true mean changes with $95 \%$ confidence intervals. 


\section{Mateus, N., Gonçalves, B., Exel, J., Esteves, P., Sampaio, J.}

Results for group and collective behaviour are presented in Table 2 and Figure 3. Likely and possible differences were observed in the stretch-index, between the regular and wider court, since the SIX in offense increased $(0.26 ; \pm 0.2$, small) while in defence decreased $(-0.22 ; \pm 0.2$, small). The SIX in offense (CV) $(-2.12 ; \pm 2)$, NearTM in defence $(-0.19 ; \pm 0.1$, $\mathrm{t}=2.17, \mathrm{p}=0.031)$ and NearTM in offense $(0.32 ; \pm 0.1)$ also presented opposed results, with the first two showing a small decrease in the larger court, and the third a small increase. Interestingly, defence NearOP (CV) $(-0.79 ; \pm 2)$ and NearTM (CV) $(0.33 ; \pm 1.7)$ showed very-likely trivial differences between the two situations.

Table 2. Descriptive analysis of players' performance measures in varied court dimension.

\begin{tabular}{|c|c|c|c|c|c|c|}
\hline & \multirow{2}{*}{\multicolumn{2}{|c|}{ Variables }} & \multicolumn{2}{|c|}{ Condition $($ mean \pm SD) } & \multirow{2}{*}{$\begin{array}{c}\text { Difference in means } \\
\text { (raw; } \pm 95 \% \mathrm{CL})\end{array}$} & \multirow{2}{*}{$\begin{array}{l}\text { Practical } \\
\text { Inferences }\end{array}$} \\
\hline & & & regular & large & & \\
\hline \multicolumn{7}{|c|}{ Group and team behaviour } \\
\hline \multirow{4}{*}{ 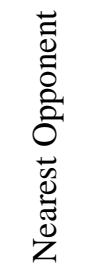 } & \multirow{2}{*}{ Average } & offense & $2.81 \pm 0.95$ & $3.02 \pm 1.16$ & $0.21 ; \pm 0.1 *$ & possible $\uparrow$ \\
\hline & & defence & $2.72 \pm 0.93$ & $2.79 \pm 0.96$ & $0.07 ; \pm 0.1$ & likely trivial \\
\hline & \multirow{2}{*}{$\mathrm{CV}$} & offense & $44.95 \pm 16.73$ & $43.65 \pm 16.21$ & $-1.29 ; \pm 2.2$ & likely trivial \\
\hline & & defence & $43.79 \pm 14.71$ & $43 \pm 15.16$ & $-0.79 ; \pm 2.0$ & very likely trivial \\
\hline \multirow{4}{*}{ 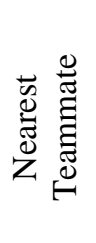 } & \multirow{2}{*}{ Average } & offense & $4.07 \pm 1.05$ & $4.39 \pm 1.12$ & $0.32 ; \pm 0.1 * *$ & likely $\uparrow$ \\
\hline & & defence & $3.41 \pm 1.01$ & $3.21 \pm 0.92$ & $-0.19 ; \pm 0.1^{*}$ & possible $\downarrow$ \\
\hline & \multirow{2}{*}{$\mathrm{CV}$} & offense & $34.56 \pm 10.71$ & $32.72 \pm 10.44$ & $-1.84 ; \pm 1.4 *$ & possible $\downarrow$ \\
\hline & & defence & $35.77 \pm 13.85$ & $36.09 \pm 12.01$ & $0.33 ; \pm 1.7$ & very likely trivial \\
\hline \multirow{4}{*}{ 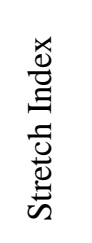 } & \multirow{2}{*}{ Average } & offense & $4.54 \pm 0.83$ & $4.8 \pm 0.62$ & $0.26 ; \pm 0.2$ & likely $\uparrow$ \\
\hline & & defence & $3.73 \pm 0.73$ & $3.52 \pm 0.71$ & $-0.22 ; \pm 0.2$ & possible $\downarrow$ \\
\hline & \multirow{2}{*}{$\mathrm{CV}$} & offense & $20.74 \pm 7.01$ & $18.63 \pm 6.59$ & $-2.12 ; \pm 2.0$ & possible $\downarrow$ \\
\hline & & defence & $21.03 \pm 10.6$ & $20.79 \pm 8.96$ & $-0.25 ; \pm 2.9$ & unclear \\
\hline 总 & \multicolumn{2}{|c|}{ Average } & $2.34 \pm 0.97$ & $2.47 \pm 1.11$ & $0.13 ; \pm 0.3$ & possible $\uparrow$ \\
\hline.$\stackrel{\tilde{D}}{0}$ & \multicolumn{2}{|c|}{$\mathrm{CV}$} & $50.46 \pm 19.25$ & $46.89 \pm 17.75$ & $-3.56 ; \pm 5.5$ & possible $\downarrow$ \\
\hline
\end{tabular}

Legend: *statistically significant differences at $\mathrm{p}<.05 ; * *$ statistically significant differences at $\mathrm{p}<.001$. Symbols: $\downarrow=$ decrease; $\uparrow=$ increase. 


\section{Effects of increasing the court on basketballers' performance}

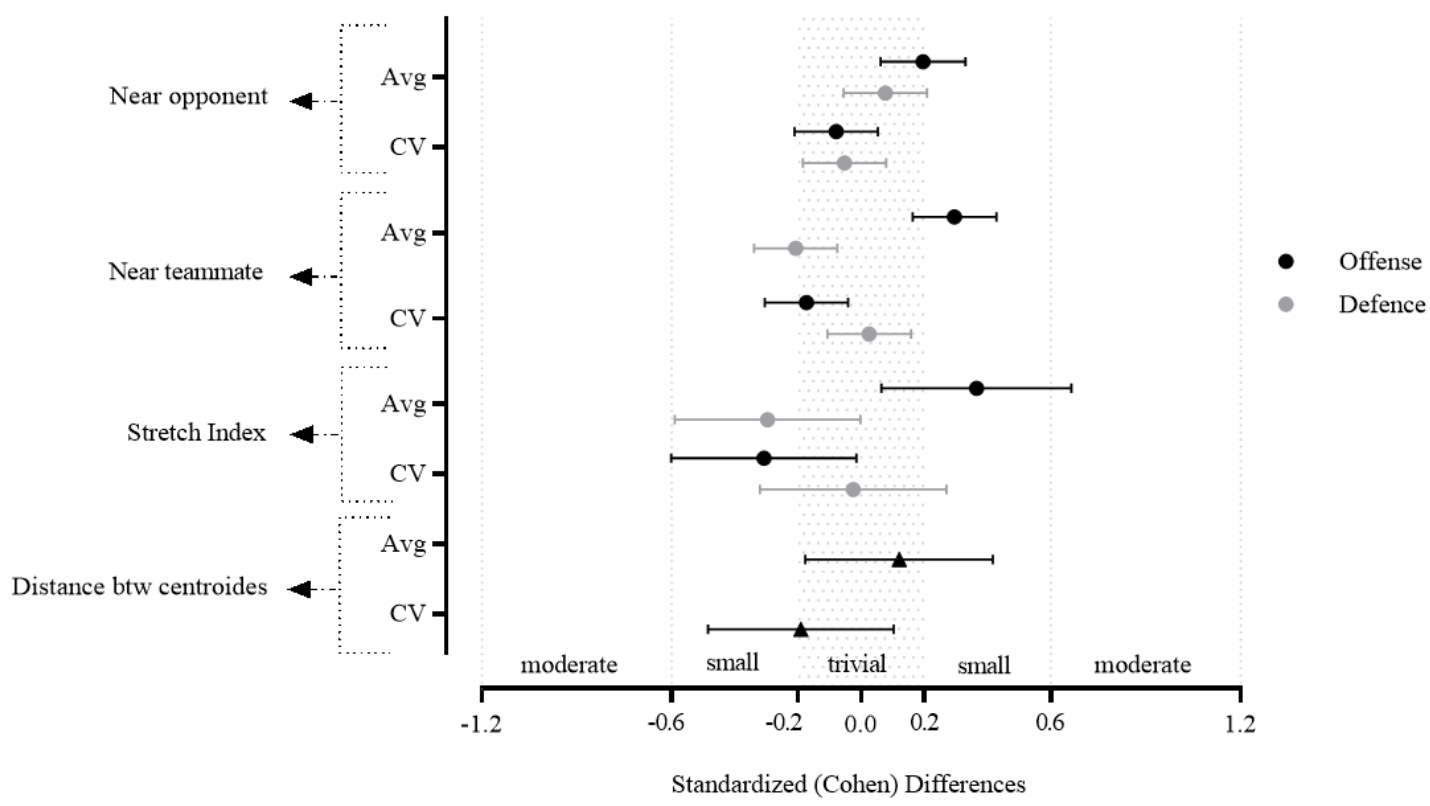

Figure 3. Standardized (Cohen) differences of team collective behaviours variables according to game condition analysis. Error bars indicate uncertainty in the true mean changes with $95 \%$ confidence intervals. Abbreviations: $\mathrm{Avg}=$ average; $\mathrm{CV}=$ coefficient of variation.

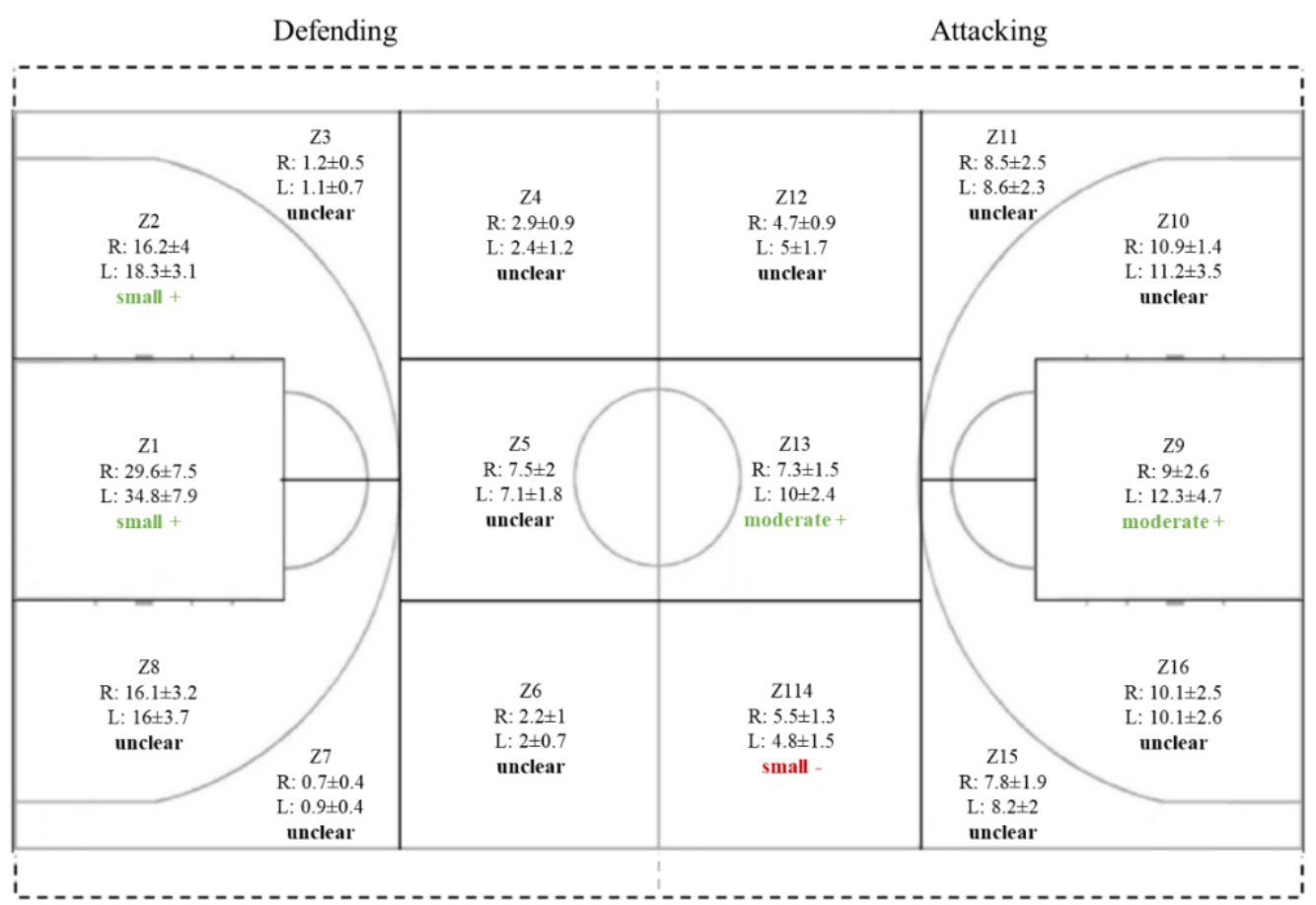

Figure 4. Difference in means and practical inferences of players' court zones occupation. Abbreviations: $\mathrm{R}=$ regular court; $\mathrm{L}=$ larger court. 


\section{Mateus, N., Gonçalves, B., Exel, J., Esteves, P., Sampaio, J.}

The court areas coverage is illustrated in Figure 4. During the teams' offense phase, the exploration of closer areas to the basket (zone 9) and central areas of the court (zone 13) was greater in the wider court than in the regular court condition. A relatively similar trend was observed in the defensive phase, as a greater exploration of the closer areas to the defensive basket was identified in the wider court condition (zones 1 and 2).

\section{DISCUSSION}

This study aimed to identify short-term effects in basketball players' physical, technical and tactical performance, when court dimension is increased 1-m wide in each side. Several positional-derived variables were computed by considering players' displacement trajectories during the games, and the players' technical and tactical actions were also measured. In general, few differences were noticed in the players' overall performance, with the exception of slight dissimilarities in offensive behaviours - players' displacement, teams' dispersion and distance between teammates. Thus, the results may suggest that the defensive placement adopted by players, and consequently by the team, are closely related to the custom court spatial references.

It is well known that augmenting the playing space facilitates the emergence of affordances related with specific technical and tactical actions, since the distance between teammates and opponents tend to be higher, and, consequently, more space becomes available for the offensive team to exploit. Conversely, restricted spaces favour defensive players in ball recovering (Frencken et al., 2013). Contrary to what was expected, enlarging the court size did not appear to influence technical variables related to ball possession such as dribble drives. In fact, only steals decreased from regular to wider court condition. As previously stated, these changes could be the result of greater available space between defensive teammates, that would reduce the opportunity to steal the ball (e.g. defensive help movements). However, the results found on defensive NearTM and SIX do not support this interpretation, as their values decrease from regular to wider court condition. Although speculative, these somewhat contradictory results can derive from the team defensive behaviour, inasmuch as a slightly higher defensive cohesion limited the occasions to steal the ball (Sampaio et al., 2016).
Research has previously stated how the increase of court size may lead to a concomitant increase in the physical load, with special emphasis on high-intensity actions and distance covered (Vazquez-Guerrero et al., 2018). However, in our study, only changes in lowintensity displacements (i.e., walking time decreased while jogging increased, from regular to wider court) were noticed. The average NearTM and SIX in offense indicated that teams were more spread in the wider court, whereby players performed higher amount of demanding movements to achieve a balanced space occupation (Coutinho et al., 2018), as offensive actions usually emerge based on more controlled sets (Bazanov, Võhandu, \& Haljand, 2006). In fact, it is known that teams' tactical performance influences players' movement trajectories and speed levels (Sampaio, Lago, Goncalves, Macas, \& Leite, 2014). On the other hand, during defence, trivial differences in walking, jogging and running were identified, suggesting that players do not adapt their movement behaviour based on opponents positioning, but based on specific spatial references, such as the lane' boundaries and the basket location.

As mentioned above, the team performance results showed that offense NearTM and SIX values increased in the wider court, suggesting that teams took advantage of the larger space to play. From this spreader playing patterns, it was expected that subjects exhibited exploratory behaviours of searching for individual solutions, because in the more spaced competitive environments, youth tend to solve the tasks more individually, by trying to be closer to the ball instead of employing a collective team approach (Folgado, Lemmink, Frencken, \& Sampaio, 2014). Although no variables related to the teams' synchronization were considered in this study, it is not unreasonable to suggest that the offensive and defensive team did not change their shape structure in the same way (i.e., not expanded and contracted together) (Bourbousson, Seve, \& McGarry, 2010). Though only man-to-man defence was used, the DbC increased and the defence SIX and NearTM decreased, between the regular and larger court games, which helps to explain why the offense did not take advantage of the greater space created, and consequently, the emergence of more scoring opportunities or passes to the basket were not observed. In fact, team sports research already reported that players' behaviours and interpersonal 


\section{Effects of increasing the court on basketballers' performance}

coordination tend to be both deliberately and unintentionally synchronized with the opponents' actions and that their individual' decisions are shaped by their spatial distance, especially in novice and amateur competitions (Esteves, de Oliveira, \& Araújo, 2011). As aforementioned, it might be suggested that the defensive positioning was influenced by the court spatial references, with the subjects continuing to follow the standard references, perhaps felt safer in less exposed areas or were not able to extract pertinent information about the offensive players' movements, neither anticipate the new environment (Dicks, Davids, \& Button, 2009; Esteves et al., 2011).

Interestingly, and contrary to what could be thought, during offence, teams do not occupy the additional meter on each side of the court. However, in previous studies, the availability of more lateral space was promptly used by players as viable solution to explore other playing possibilities, which was reflected in teams' displacement (Frencken et al., 2013; Gonçalves et al., 2017). In fact, a crucial feature of sports expertise is the ability of skilled athletes to successfully use information that specifies properties of their surroundings, to guide their anticipatory responses (Davids \& Baker, 2007; Dicks et al., 2009). In the case of our study, young players might present difficulties to attune to the key environmental properties that may specify the opportunities to explore free spaces (Dicks et al., 2009; Esteves et al., 2011), and consequently, be unable to modulate their actions from the regular to the wider court. In the present study, playing in the wider court reflected a higher occupation of the closer areas to the opponent scoring target along with central areas of the court. These changes, combined with the variations observed in tactical variables might suggest that in the wider court, the greater tendency for exploring the central areas of the court. Defensively, teams appear to favour spatial exploration near their own scoring target. It might be assumed that this defensive pattern may stand as a strategy to counter the spaces explored by the opponent team, through the use of a greater defensive help actions.

Although this study adds relevant findings regarding the short-term effects of expanding the court' width on youth players' performance, some limitations should be acknowledged. Firstly, the lower sample size used in this study may limit the generalization of results.
Moreover, it is also likely that different results may emerge with older players and with players of different expertise since they interact differently with the environmental information (Dicks et al., 2009). Additionally, the short game's length may have also compromised the players' adaptation to the new competitive environment.

\section{CONCLUSIONS \\ AND \\ PRACTICAL APPLICATIONS}

This study presents new insights into the short-term effects on youth basketballers' technical, physical and positional performance when the court dimension is increased 1-m wide to each side. When playing in the wider court condition, the dispersion of player's displacement trajectories during the offensive phase increased, which had slight consequences on their physical responses and in the teams' playing patterns. Indeed, increase team distribution on the court, requires a faster perception and action from players and a higher level of team coordination, which can only be achieved if players have a common understanding of their task, their teammates' roles and about the environment in which they operate. Conversely, the short-term changes in defence suggested that players movements are guided according to spatial references, such as the basket location, the lane' boundaries and the three point-line. In line with this reasoning, coaching staffs should be aware that informational constraints might require longer time-scales to yield robust changes in players' decisions, whereby, further research is required to investigate the time-effect.

\section{FUNDING}

This study was supported by the Portuguese Foundation for Science and Technology (FCT), and European Social Fund (ESF), through a Doctoral grant endorsed to the first author (SFRH/BD/138499/2018) under the Human Potential Operating Program (POPH). Project NanoSTIMA: Macro-to-Nano Human Sensing: Toward Integrated Multimodal Health Monitoring and Analytics, NORTE-01-0145FEDER-000016, Fundo Europeu de Desenvolvimento Regional (FEDER) - NORTE 2020.

\section{REFERENCES}




\section{Mateus, N., Gonçalves, B., Exel, J., Esteves, P., Sampaio, J.}

1. Atl, H., Köklü, Y., Alemdaroglu, U., \& Koçak, F. (2013). A comparison of heart rate response and frequencies of technical actions between halfcourt and full-court 3-a-side games in high school female basketball players. The Journal of Strength \& Conditioning Research, 27(2), 352-356. https://doi.org/10.1519/jsc.0b013e3182542674

2. Ato, M., López-García, J., \& Benavente, A. (2013). Un sistema de clasificación de los diseños de investigación en psicología. Anales de Psicología/Annals of Psychology, 29(3), 10381059.

https://doi.org/10.6018/analesps.29.3.178511

3. Bastida-Castillo, A., Gómez-Carmona, C., De la Cruz-Sánchez, E., Reche-Royo, X., Ibáñez, S., \& Pino Ortega, J. (2019). Accuracy and Inter-Unit Reliability of Ultra-Wide-Band Tracking System in Indoor Exercise. Applied Sciences, 9(5), 939. https://doi.org/10.3390/app9050939

4. Bazanov, B., Võhandu, P., \& Haljand, R. (2006). Trends in offensive team activity in basketball. Education. Physical Training. Sport, 2, 5-11. https://doi.org/10.33607/bjshs.v2i61.590

5. Bourbousson, J., Seve, C., \& McGarry, T. (2010). Space-time coordination dynamics in basketball: Part 2. The interaction between the two teams. Journal of Sports Sciences, 28(3), 349-358. https://doi.org/10.1080/02640410903503640

6. Calleja, J., Tobalina, J., Santos, R., Hidalgo, G., \& Terrados, N. (2015). Evolution of physical characteristics in mid level young basketball players $=$ Evolución de las capacidades físicas en jugadores jóvenes de baloncesto de medio nivel. Cuadernos de Psicología del Deporte. https://doi.org/10.4321/s157884232015000300022

7. Carter, J., Ackland, T., Kerr, D., \& Stapff, A. (2005). Somatotype and size of elite female basketball players. Journal of Sports Sciences, 23(10), 1057-1063. https://doi.org/10.1080/02640410400023233

8. Casamichana, D., \& Castellano, J. (2010). Timemotion, heart rate, perceptual and motor behaviour demands in small-sides soccer games: effects of pitch size. Journal of Sports Sciences, 28(14), 1615-1623. https://doi.org/10.1080/02640414.2010.521168
9. Cormery, B., Marcil, M., \& Bouvard, M. (2008). Rule change incidence on physiological characteristics of elite basketball players: a 10year-period investigation. British Journal of Sports Medicine, 42(1), 25-30. https://doi.org/10.1136/bjsm.2006.033316

10. Correia, V., Araujo, D., Craig, C., \& Passos, P. (2011). Prospective information for pass decisional behavior in rugby union. Human Movement Science, 30(5), 984-997. https://doi.org/10.1016/j.humov.2010.07.008

11. Coutinho, D., Gonçalves, B., Santos, S., Travassos, B., Wong, D. P., \& Sampaio, J. (2018). Effects of the pitch configuration design on players' physical performance and movement behaviour during soccer small-sided games. Research in Sports Medicine, 1-16. https://doi.org/10.1080/15438627.2018.1544133

12. Davids, K., \& Baker, J. (2007). Genes, environment and sport performance: why the nature-nurture dualism is no longer relevant. Sports Medicine, 37(11), 961-980. https://doi.org/10.2165/00007256-20073711000004

13. Dicks, M., Davids, K., \& Button, C. (2009). Representative task design for the study of perception and action in sport. International Journal of Sport Psychology, 40(4), 506.

14. Drinkwater, E., Pyne, D., \& McKenna, M. (2008). Design and interpretation of anthropometric and fitness testing of basketball players. Sports Medicine, 38(7), 565-578. https://doi.org/10.2165/00007256-20083807000004

15. Esteves, P., de Oliveira, R., \& Araújo, D. (2011). Posture-related affordances guide attacks in basketball. Psychology of Sport and Exercise, 12(6), 639-644. https://doi.org/10.1016/j.psychsport.2011.06.007

16. Folgado, H., Lemmink, K., Frencken, W., \& Sampaio, J. (2014). Length, width and centroid distance as measures of teams tactical performance in youth football. European Journal of Sport Science, 14 Suppl 1, S487-492. https://doi.org/10.1080/17461391.2012.730060

17. Frencken, W., Van Der Plaats, J., Visscher, C., \& Lemmink, K. (2013). Size matters: Pitch 


\section{Effects of increasing the court on basketballers' performance}

dimensions constrain interactive team behaviour in soccer. Journal of systems science and complexity, 26(1), 85-93. https://doi.org/10.1007/s11424-013-2284-1

18. Gonçalves, B., Esteves, P., Folgado, H., Ric, A., Torrents, C., \& Sampaio, J. (2017). Effects of pitch area-restrictions on tactical behavior, physical, and physiological performances in soccer large-sided games. The Journal of Strength \& Conditioning Research, 31(9), 2398-2408. https://doi.org/10.1519/jsc.0000000000001700

19. Hopkins, W. (2004). How to interpret changes in an athletic performance test. Sportscience, 8(1), 17.

20. Hopkins, W. (2017). Spreadsheets for analysis of controlled trials, crossovers and time series. Sportscience, 21, 1-4.

21. Hopkins, W., Marshall, S., Batterham, A., \& Hanin, J. (2009). Progressive statistics for studies in sports medicine and exercise science. Medicine+ Science in Sports+ Exercise, 41(1), 3. https://doi.org/10.1249/mss.0b013e31818cb278

22. Hughes, M., \& Franks, I. M. (2004). Notational analysis of sport: Systems for better coaching and performance in sport: Psychology Press.

23. Ibáñez, S., García-Rubio, J., Rodríguez-Serrano, D., \& Feu, S. (2019). Development of a Knockout Competition in Basketball: A Study of the Spanish Copa del Rey. Frontiers in Psychology, 10(2457). https://doi.org/10.3389/fpsyg.2019.02457

24. Martínez Fernández, S., García Rubio, J., \& Ibáñez, S. (2015). Incidence of type of game mode in player participation in minibasket. Revista de Psicología del Deporte, 24(1), 656-668.

25. Mateus, N., Goncalves, B., Weldon, A., \& Sampaio, J. (2019). Effects of using four baskets during simulated youth basketball games. PLOS ONE, 14(8). https://doi.org/10.1371/journal.pone.0221773

26. Piñar, M., Cárdenas, D., Alarcón, F., Escobar, R., $\&$ Torre, E. (2009). Participation of minibasketball players during small-sided competitions. Revista de Psicología del Deporte, 18(3), 445-449.

27. Puente, C., Abian-Vicen, J., Areces, F., Lopez, R., \& Del Coso, J. (2017). Physical and Physiological
Demands of Experienced Male Basketball Players During a Competitive Game. The Journal of Strength \& Conditioning Research, 31(4), 956962.

https://doi.org/10.1519/jsc.0000000000001577

28. Sampaio, J., Gonçalves, B., Mateus, N., Shaoliang, Z., \& Leite, N. (2018). 6 Basketball. Modelling and Simulation in Sport and Exercise.

29. Sampaio, J., Gonçalves, B., Rentero, L., Abrantes, C., \& Leite, N. (2014). Exploring how basketball players' tactical performances can be affected by activity workload. Science \& Sports, 29(4), e23e30. https://doi.org/10.1016/j.scispo.2013.05.004

30. Sampaio, J., Lago, C., Goncalves, B., Macas, V., \& Leite, N. (2014). Effects of pacing, status and unbalance in time motion variables, heart rate and tactical behaviour when playing 5-a-side football small-sided games. Journal of Science and Medicine in Sport, 17(2), 229-233. https://doi.org/10.1016/j.jsams.2013.04.005

31. Sampaio, J., Leser, R., Baca, A., CallejaGonzalez, J., Coutinho, D., Gonçalves, B., \& Leite, N. (2016). Defensive pressure affects basketball technical actions but not the timemotion variables. Journal of Sport and Health Science, 5(3), 375-380. https://doi.org/10.1016/j.jshs.2015.01.011

32. Aguilar Sánchez, J., Hernández-Mendo, A., Martín Martínez, I., Reigal Garrido, R.E. \& Chirosa Ríos, L.J. (2018). Efectos de un programa de juegos reducidos sobre la toma de decisiones en chicas adolescentes. Cuadernos de Psicología del Deporte, 18(1), 21-30. https://doi.org/10.4321/s157884232015000300008

33. Silva, P., Duarte, R., Sampaio, J., Aguiar, P., Davids, K., Araujo, D., \& Garganta, J. (2014). Field dimension and skill level constrain team tactical behaviours in small-sided and conditioned games in football. Journal of Sports Sciences, 32(20), 1888-1896. https://doi.org/10.1080/02640414.2014.961950

34. Toro, E., Alonso, M., \& Egido, J. (2017). Effect of rules modification and competition system on levels of satisfaction in basketball players under 14. Revista de Psicología del Deporte, 26(3), 5964. 
Mateus, N., Gonçalves, B., Exel, J., Esteves, P., Sampaio, J.

35. Vazquez-Guerrero, J., Reche, X., Cos, F., Casamichana, D., \& Sampaio, J. (2018). Changes in External Load When Modifying Rules of 5-on5 Scrimmage Situations in Elite Basketball. The Journal of Strength \& Conditioning Research. https://doi.org/10.1519/jsc.0000000000002761 